\title{
Yield benefits of pasture mixtures with species drilled in the same and alternate rows
}

\author{
A.D. BLACK, S. ANDERSON, S.K. DALGETY, C.A. HASSALL, T.S. MYINT and S.R. VREUGDENHIL
}

Field Research Centre, Department of Agricultural Sciences, PO Box 85084, Lincoln University, Lincoln 7647, New Zealand alistair.black@lincoln.ac.nz

\begin{abstract}
This study investigated the effect of sowing species in alternate drill rows on dry matter (DM) yield of pasture mixtures. Seven mixtures of 'Base' perennial ryegrass, 'Tonic' plantain and 'Apex' white clover (three pure, three binary and one ternary) were drilled into plots in March 2015 at Lincoln University. Binary and ternary mixtures were also sown with species in alternate drill rows. Ryegrass-white clover and plantain-white clover mixtures yielded more than the average monoculture yields of their constituent species (over-yielding). This diversity effect averaged $7.01 \mathrm{t} \mathrm{DM} /$ ha in Year 1 $(2015 / 2016)$ and 3.45 t DM/ha in Year $2(2016 / 2017)$ of sown yield (total minus weeds) when species were drilled together. Diversity effects were due to synergistic interactions and white clover interacted more strongly with plantain than ryegrass. There was no additional yield benefit from increasing the number of species from two to three in the mixture, and from sowing species in alternate rows.
\end{abstract}

Keywords: diversity, establishment, plantain, ryegrass, simplex design, sowing method, white clover

\section{Introduction}

Maximising animal production through increased intake of high quality forage is an important aim of pasture renewal. Traditionally, high quality forage has been produced from pasture mixtures of perennial ryegrass (Lolium perenne) and white clover (Trifolium repens). Plantain (Plantago lanceolata) and other herb and legume species have also been added to pasture mixtures in an attempt to improve pasture production and quality. However, the question is which species to include in a pasture mixture? To help answer this question, information is needed about how different species contribute to pasture function (e.g., herbage yield, lamb liveweight gain, weed suppression and nutrient leaching).

This experiment focussed on mixtures of perennial ryegrass, plantain and white clover to assist the design of seed mixtures that maximise herbage yield. The experiment used a modelling framework (Kirwan et al. 2009) that quantified the effects of species identity and diversity on yield, and allowed the prediction of yield for any composition of the three species. The identity effect is the monoculture yield of each species. The diversity effect is the combined effect of multiple interspecific interactions (e.g., niche partitioning and facilitation) among species in a pasture. Interspecific interactions may differ in direction (i.e., synergistic or antagonistic) and magnitude, and may involve two or more species. The contributions of species' identities and interactions to pasture function are weighted by the initial proportions of species in the pasture. The initial species' proportions were defined as the relative proportions of species in the seed mixtures based on seed number. For a study over several periods, initial species' proportions may then be the composition of yield from the previous harvest or year.

In this paper, we build on a previous analysis of the first 2 years of data from this continuing experiment (Black et al. 2017) and report the effects of a sowing method - physical separation of species in alternate drill rows - on species interactions over the same 2-year period. This sowing method requires a specialised or modified seed drill used by some farmers to improve the success of slow-establishing species such as white clover (Hurst et al. 2000). The expectation is that physical separation of species will create a pasture mixture with a more balanced and stable species composition and thereby enhance species identity and diversity effects. However, this has not been confirmed in practice.

\section{Methods}

\section{Experimental design and site}

Seven mixtures of 'Base' perennial ryegrass, 'Tonic' plantain and 'Apex' white clover (three pure, three binary and one ternary) were defined using a simplex centroid design (Cornell 2002). As the objective was to maximise yield of highly digestible forage from intensively managed pastures, the chosen species and cultivars were all high yielding and high quality types suitable for fertile, irrigated sites in New Zealand (Stewart et al. 2014). To test the effect of physical separation of species on interspecific interactions, the species in the binary and ternary mixtures were sown together and in alternate drill rows. The 11 mixturesowing method combinations were randomly assigned to $2.1 \times 6.0 \mathrm{~m}$ plots within each of four replicates.

The experiment was located at the Horticultural 
Research Area, Lincoln University, Lincoln, New Zealand $\left(43^{\circ} 38^{\prime} 53.1^{\prime \prime} \mathrm{S} 172^{\circ} 27^{\prime} 11.7^{\prime \prime} \mathrm{E}\right.$ and $10 \mathrm{~m}$ elevation) on a Templeton silt loam soil (Cox 1978). The site had been in lucerne (Medicago sativa) in 2011 and 2012, oilseed rape (Brassica napus) in 2013 and forage oats (Avena sativa) in 2014. Rainfall was 200 $\mathrm{mm}$ for 1st March-30th June 2015, $493 \mathrm{~mm}$ for 1st July 2015-30th June 2016 and $462 \mathrm{~mm}$ for 1st July 2016-26th May 2017. Average monthly air temperature ranged between $4^{\circ} \mathrm{C}$ in July and $16^{\circ} \mathrm{C}$ in January.

\section{Mixture establishment and management}

White clover seed was coated with Mo, lime, insecticide and fungicide (Agricote Clover $\left.{ }^{\circledR}\right)$. Ryegrass and plantain seed was not treated. Thousand seed weight (TSW) was 3.6, 2.7 and $0.9 \mathrm{~g}$ and germination was 93,99 and $91 \%$ for ryegrass, plantain and white clover, respectively. The sowing rate of the ryegrass monoculture was $30 \mathrm{~kg} / \mathrm{ha}$. This sowing rate and the TSW of ryegrass were applied to calculate its equivalent seed population as $833 \mathrm{seeds} / \mathrm{m}^{2}$. Then, this value, the TSWs of the other species and the species compositions in the experimental design were used to calculate the sowing rates of each species in the mixtures (Table 1). Sowing rate was not adjusted for germination percentage.

The site was cultivated in November 2014 and sprayed (Roundup Ultra ${ }^{\circledR}$ Max: $570 \mathrm{~g} / \mathrm{L}$ glyphosate at $3 \mathrm{~L} / \mathrm{ha})$, irrigated $(60 \mathrm{~mm})$ and re-cultivated into a seedbed in February-March 2015. The mixtures were sown on 26th March 2015 using a precision drill with 14 coulters spaced $150 \mathrm{~mm}$ apart (Flexiseeder, Christchurch, New Zealand). The drill was capable of sowing up to three species in alternate rows. Sowing depth was 10-15 mm.

Table 1

Sowing rates $(\mathrm{kg} / \mathrm{ha})$ of seven mixtures varying in proportions of 'Base' perennial ryegrass (RG), 'Tonic' plantain (P) and 'Apex' white clover (WC) at a total seed population of 833 seeds $/ \mathrm{m}^{2}$ (equivalent to $30 \mathrm{~kg} / \mathrm{ha}$ of 'Base').

\begin{tabular}{lcccc}
\hline & \multicolumn{3}{c}{ Species } & \\
\cline { 2 - 4 } Mixture & RG & P & WC & Total \\
\hline Pure & 30 & 0 & 0 & 30 \\
Pure & 0 & 22.5 & 0 & 22.5 \\
Pure & 0 & 0 & 7.5 & 7.5 \\
Binary & 15 & 11.25 & 0 & 26.25 \\
Binary & 15 & 0 & 3.75 & 18.75 \\
Binary & 0 & 11.25 & 3.75 & 15 \\
Ternary & 10 & 7.5 & 2.5 & 20 \\
\hline
\end{tabular}

Sowing rate $(\mathrm{kg} / \mathrm{ha})=833$ seeds $/ \mathrm{m}^{2} \times$ thousand seed weight $(\mathrm{g}) / 1000 \times 1$ $\mathrm{kg} / 1000 \mathrm{~g} \times 10000 \mathrm{~m}^{2} / 1$ ha $\times$ species proportion
The plots were grazed by sheep eight times/year: 16th August (cut instead of grazed to minimise damage to the new pastures), 22nd-25th September, 27th-30th October, 1st-3rd December, 7th-11th January, 16th22nd February, 1st-5th April and 27th-30th May in Year $1(2015 / 2016)$ and 2nd-5th August, 26th-30th September, 1st-7th November, 9th-13th December, 16th-19th January, 17th-21st February, 31st March7th April and 26th-30th May in Year 2 (2016/2017). This management resulted in the average pre-grazing herbage mass (HM) ranging from 1.0 to $3.5 \mathrm{t} \mathrm{DM} /$ ha. Enough sheep were used to consume most of the herbage and the residual was trimmed to $4-5 \mathrm{~cm}$.

Soil fertility (4th May 2015) was: pH 5.7, Olsen P $13 \mathrm{mg} / \mathrm{L}, \mathrm{Ca} 7.3 \mathrm{me} / 100 \mathrm{~g}, \mathrm{Mg} 0.84 \mathrm{me} / 100 \mathrm{~g}, \mathrm{~K} 0.32$ me/100 g, Na $0.17 \mathrm{me} / 100 \mathrm{~g}$ and sulphate $\mathrm{S} 13 \mathrm{mg} /$ kg. Superphosphate ( $9 \%$ P, $11 \% \mathrm{~S})$ was applied on 30th September $2015(500 \mathrm{~kg} / \mathrm{ha})$ and 12th October 2016 (480 kg/ha). Irrigation was applied at 3-5 week intervals from 30th October 2015 to 6th April 2016 (360 mm) and from 9th November 2016 to 15th February 2017 $(260 \mathrm{~mm})$ to maintain soil moisture above a critical limit of $24 \%$ of soil volume (Black \& Murdoch 2013). T-MaxTM (30 g/L aminopyralid at $2 \mathrm{~L} / \mathrm{ha}$ ) was used to remove volunteer white clover from the ryegrass plots on 10th March 2017 and the plantain and ryegrassplantain plots on 5th May 2017. DewTM $600(600 \mathrm{~g} / \mathrm{L}$ diazinon at $4 \mathrm{~L} / \mathrm{ha}$ ) was sprayed on all plots to control grass grub (Costelytra zealandica) on 10th May 2017.

\section{Measurements}

Before each grazing, one quadrat/plot was clipped to $1-2 \mathrm{~cm}$ above ground level, bagged and stored at $3-4^{\circ} \mathrm{C}$. The quadrat area was $0.30 \mathrm{~m}^{2}(1 \mathrm{~m}$ of two adjacent rows) except for plots with three species sown in alternate rows, which required a $0.45 \mathrm{~m}^{2}$ quadrat $(1 \mathrm{~m}$ of three adjacent rows). Within 1-4 days of sampling, a subsample of at least 400 pieces was separated into each sown and total weed species. As volunteer plants of the sown species could not be separated from sown plants, they did not contribute to the weed fraction. Volunteer plants of experimental species that were not sown in a plot were included in the weed fraction. The separated components and the remainder of the quadrat sample were dried at $65^{\circ} \mathrm{C}$ and weighed to determine HM. Because the post-grazing residual was trimmed to $3-4 \mathrm{~cm}$, and the quadrats were cut to $1-2$ $\mathrm{cm}$, the residual HM had to be estimated. To do this, one 0.30 , or occasionally $0.20 \mathrm{~m}^{2}$ quadrat/monoculture plot was clipped to $1-2 \mathrm{~cm}$ above ground and dried at $65^{\circ} \mathrm{C}$. Residual $\mathrm{HM}$ was calculated as the average monoculture residual/replicate, weighted by species' proportions in the previous pre-grazing HM. The DM yield of each grazing was calculated as pre-grazing HM minus the previous residual HM. This was multiplied 
by the proportions of sown species and weed in the subsample to determine their yields. Yields were summed across harvests for Years 1 (sowing to 27th May 2016) and 2 (30th May 2016 to 26th May 2017).

\section{Data analysis}

Total yield (annual DM yield) and sown yield (annual DM yield of sown species) were analysed for effects of mixture and sowing method in each year by analysis of variance (ANOVA) using the statistical software Genstat ${ }^{\circledR}$ 18. Means were compared using Fisher's least significant difference test $\quad(\alpha=0.05)$. Overyielding (mixture yielding more than the weighted average monoculture yield of the constituent species) was tested using a paired samples t-test.

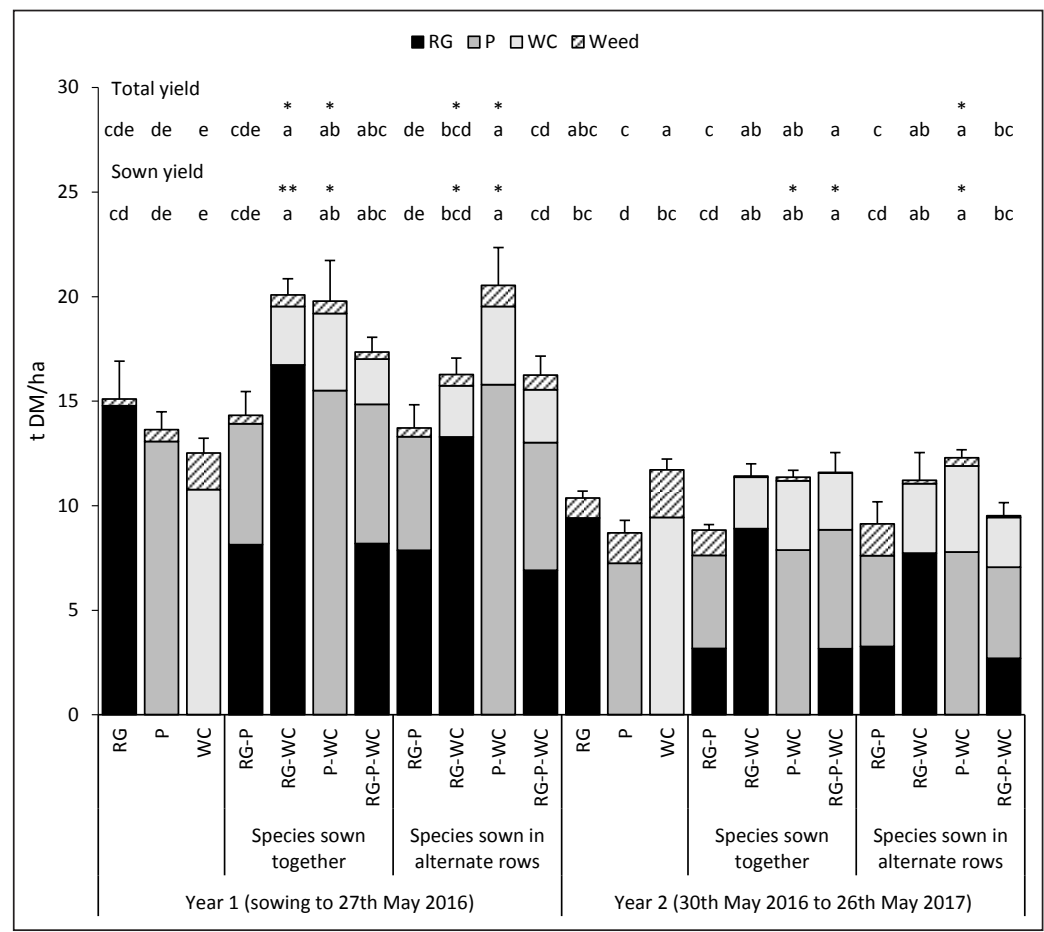

Figure 1 Total, sown species and weed dry matter (DM) yields for monocultures and mixtures of perennial ryegrass (RG), plantain (P) and white clover (WC) with species sown together and in alternate drill rows for each year at Lincoln University. Asterisks indicate significance of test for over-yielding $\left({ }^{*} \mathrm{P}<0.05\right.$, $\left.{ }^{* *} \mathrm{P}<0.01\right)$ and means with different letters are significantly different $(\mathrm{P}<0.05)$ within year for total and sown yields. Error bars are standard errors of means for total yield.
This additional yield is the

diversity effect. A repeated measures analysis tested whether treatment effects depended on year.

Total and sown yields were also analysed as functions of the proportions of sown species in the mixtures by fitting a quadratic model to the data using Minitab® 18. The model was:

$\hat{y}=\beta_{1} x_{1}+\beta_{2} x_{2}+\beta_{3} x_{3}+\beta_{12} x_{1} x_{2}+\beta_{13} x_{1} x_{3}+\beta_{23} x_{2} x_{3}$ $+\beta_{123} x_{1} x_{2} x_{3}+\beta_{12} x_{1} x_{2} M+\beta_{13} x_{1} x_{3} M+\beta_{23} x_{2} x_{3} M+$ $\beta_{123} \mathrm{x}_{1} \mathrm{x}_{2} \mathrm{x}_{3} \mathrm{M}+\varepsilon$ (Equation 1)

where $\hat{y}$ is the predicted yield of a mixture. The variables $\mathrm{x}_{1}, \mathrm{x}_{2}$ and $\mathrm{x}_{3}$ are the proportions of ryegrass, plantain and white clover, respectively, in the seed mixtures for Year 1 and in the sown yield from the previous year for Year 2. $\beta_{1}, \beta_{2}$ and $\beta_{3}$ are estimates of the monoculture yields (identity effects). $\beta_{12}, \beta_{13}$ and $\beta_{23}$ represent the interaction effects for the combination of two species and $\beta_{123}$ is the additional interaction between three species. Species identity and interaction effects are weighted by the initial species' proportions. The diversity effect of a mixture is the sum of the four species interaction terms. Terms with ' $M$ ' test the effect of sowing method on species interactions (' $\mathrm{M}$ ' was coded -1 for species mixed together and 1 for species separated in alternate rows). $\varepsilon$ is the residual. The
ANOVA tested if the estimated regression coefficients were significantly different $(\mathrm{P}<0.05)$ from zero or not. There were no t-tests and $\mathrm{P}$ values for the first three coefficients because the model does not have an intercept term.

\section{Results and Discussion}

Total yield, sown species yields and weed yield are shown for each sward in each year (Figure 1). Total and sown yields were affected by sward type $(\mathrm{P}<0.001)$ and, for total yield, this effect depended on year $(\mathrm{P}<0.05)$. In Year 1 , the identity effect averaged $13.75 \mathrm{t}$ of total DM/ha for all species, and $14.78 \mathrm{t}$ of sown DM/ ha for ryegrass compared with $10.77 \mathrm{t}$ of sown $\mathrm{DM} / \mathrm{ha}$ for white clover. The diversity effect averaged $6.48 \mathrm{t}$ of total DM/ha and $7.01 \mathrm{t}$ of sown $\mathrm{DM} /$ ha for ryegrasswhite clover and plantain-white clover with species sown together (over-yielding), and both mixtures exceeded the best monoculture of their constituent species (transgressive over-yielding). The diversity effect was lower for ryegrass-white clover with species sown in alternate drill rows at $2.46 \mathrm{t}$ of total DM/ha and $2.95 \mathrm{t}$ of sown DM/ha. In Year 2, the identity effect of white clover was about $2 \mathrm{t} \mathrm{DM} /$ ha greater than plantain. 
The diversity effect averaged $3.23 \mathrm{t}$ of sown DM/ha for plantain-white clover and ryegrass-plantain-white clover with species sown together, and $3.06 \mathrm{t}$ of total $\mathrm{DM} /$ ha and $4.26 \mathrm{t}$ of sown $\mathrm{DM} /$ ha for plantain-white clover with species in alternate rows.

The relative abundance of species changed from the seed mixture proportions to the sown yield for each year (Figure 1). The sown species composition of the binary and ternary mixtures, expressed as proportions of sown yield, averaged 0.59:0.41, 0.85:0.15, 0.81:0.19 and 0.46:0.39:0.15 in Year 1, and 0.42:0.58, 0.74:0.26, 0.68:0.32 and 0.28:0.48:0.24 in Year 2, across both sowing methods for ryegrass-plantain, ryegrass-white clover, plantain-white clover and ryegrass-plantainwhite clover, respectively. Weed yield as a proportion of total yield was 0.14 for white clover and 0.02-0.05 for the other 10 swards in Year 1, and 0.09 for ryegrass, 0.17 for plantain, 0.19 for white clover, $0.13-0.17$ for ryegrass-plantain and 0-0.03 for ryegrass-white clover, plantain-white clover and ryegrass-plantain-white clover in Year 2. The relative proportions of species present in the swards determined the contribution of identity and diversity effects to yield.

The mixture regression model quantified the separate interspecific interactions that resulted in the diversity effects and over-yielding (Table 2). The coefficients for the linear terms were equal to the identity effects already shown (Figure 1). The coefficients for the quadratic terms indicated differences between the three pairwise interaction effects on yield in each year (Table 2). There was no interaction between ryegrass and plantain. Both ryegrass and plantain interacted positively with white clover, with the interaction stronger for plantain (as indicated by the larger coefficients). These coefficients represent the potential of the species involved to interact in an even mixture, and can be used to calculate the diversity effect. For example, the diversity effect of a 50:50 mixture of ryegrass-white clover in Year 1 was $4.36 \mathrm{t}$ of total DM/ha $(17.45 \times 0.5 \times 0.5)$ and $4.85 \mathrm{t}$ of sown DM/ha $(19.41 \times 0.5 \times 0.5)$. By comparison, the diversity effect of a 50:50 mixture of plantain-white clover was greater at $7.08 \mathrm{t}$ of total DM/ha $(28.32 \times$ $0.5 \times 0.5)$ and $7.34 \mathrm{t}$ of sown DM/ha $(29.36 \times 0.5 \times$ $0.5)$. There may be several explanations for this result, including possible differences in soil $\mathrm{N}$ status (Andrews et al. 2011), plant and tiller/stolon densities (Harris \& Thomas 1973), leaf canopy structure and light interception (Black et al. 2009). These explanations need further investigation.

There was no additional interaction between all three species (Table 2) and therefore no additional benefit to yield from increasing the number of sown species (richness) from two to three in the mixture. This explained the similar yields and less over-yielding for the three-species mixture compared with ryegrasswhite clover and plantain-white clover (Figure 1). The diversity effect for sown yield from the three-species mixture in Year 2 was due to the pairwise interactions of white clover with ryegrass and plantain in the mixture. The diversity effect for an even $(1 / 3-1 / 3-1 / 3)$ three-species mixture in Year 2 was $4.26 \mathrm{t}$ of sown DM/ha $(-3.73 \mathrm{x}$ $1 / 9+14.04 \times 1 / 9+25.03 \times 1 / 9+9.00 \times 1 / 27)$. This value was less than the diversity effects calculated for even ryegrass-white clover and plantain-white clover mixtures, indicating that ryegrass and plantain had a greater potential to interact with white clover when they

Table 2 Estimated regression coefficients for each year.

\begin{tabular}{|c|c|c|c|c|c|c|c|c|c|c|c|c|}
\hline \multirow[t]{3}{*}{ Term } & \multicolumn{6}{|c|}{ Year 1} & \multicolumn{6}{|c|}{ Year 2} \\
\hline & \multicolumn{3}{|c|}{ Total yield } & \multicolumn{3}{|c|}{ Sown yield } & \multicolumn{3}{|c|}{ Total yield } & \multicolumn{3}{|c|}{ Sown yield } \\
\hline & Coef. & $\begin{array}{c}\text { SE } \\
\text { Coef. }\end{array}$ & $\begin{array}{c}\mathbf{P} \\
\text { value }\end{array}$ & Coef. & $\begin{array}{c}\text { SE } \\
\text { Coef. }\end{array}$ & $\begin{array}{c}P \\
\text { value }\end{array}$ & Coef. & $\begin{array}{l}\text { SE } \\
\text { Coef. }\end{array}$ & $\begin{array}{c}P \\
\text { value }\end{array}$ & Coef. & $\begin{array}{c}\text { SE } \\
\text { Coef. }\end{array}$ & $\begin{array}{c}\mathrm{P} \\
\text { value }\end{array}$ \\
\hline$R G$ & 15.10 & 1.24 & - & 14.78 & 1.24 & - & 10.36 & 0.717 & - & 9.41 & 0.723 & - \\
\hline$P$ & 13.63 & 1.24 & - & 13.07 & 1.24 & - & 8.70 & 0.717 & - & 7.24 & 0.723 & - \\
\hline WC & 12.52 & 1.24 & - & 10.77 & 1.24 & - & 11.70 & 0.717 & - & 9.44 & 0.723 & - \\
\hline$R G^{*} P$ & -1.42 & 4.95 & 0.78 & -1.27 & 4.94 & 0.80 & -2.90 & 2.98 & 0.34 & -3.73 & 3.01 & 0.22 \\
\hline$R G * W C$ & 17.45 & 4.95 & 0.001 & 19.41 & 4.94 & $<0.001$ & 5.87 & 6.28 & 0.36 & 14.04 & 6.33 & 0.03 \\
\hline$P^{*} W C$ & 28.32 & 4.95 & $<0.001$ & 29.76 & 4.94 & $<0.001$ & 16.43 & 5.04 & 0.01 & 25.03 & 5.08 & $<0.001$ \\
\hline$R G^{*} P^{*} W C$ & -51.00 & 30.50 & 0.10 & -51.80 & 30.40 & 0.10 & -6.20 & 29.9 & 0.84 & 9.00 & 30.1 & 0.77 \\
\hline$R G^{\star} P^{\star} M$ & -1.21 & 3.50 & 0.73 & -1.25 & 3.49 & 0.72 & 0.62 & 2.09 & 0.77 & -0.03 & 2.11 & 0.99 \\
\hline$R G^{*} W C^{\star} M$ & -7.62 & 3.50 & 0.04 & -7.60 & 3.49 & 0.04 & -0.77 & 3.98 & 0.85 & -1.22 & 4.01 & 0.76 \\
\hline$P^{*} W C^{*} M$ & 1.52 & 3.50 & 0.67 & 0.67 & 3.49 & 0.85 & 3.00 & 3.27 & 0.37 & 2.29 & 3.29 & 0.49 \\
\hline$R G^{*} P^{*} W C^{*} M$ & 7.1 & 29.80 & 0.81 & 4.9 & 29.80 & 0.87 & -47.70 & 27.0 & 0.09 & -41.90 & 27.2 & 0.13 \\
\hline
\end{tabular}

$R G=$ ryegrass, $P=$ plantain, $W C=$ white clover, $M=$ sowing method, $S E=$ standard error. Significant $(P<0.05)$ terms are highlighted. 
were the only companion species rather than when they were in the same mixture.

The degree of expression of the interactions between two species (Table 2) depended on the relative abundance of the species involved (Figure 1). For example, in Year 1, the diversity effect of a $90 \%$ ryegrass- $10 \%$ white clover mixture was only $1.57 \mathrm{t}$ of total DM/ha $(17.45 \times 0.9 \times 0.1)$ and 1.75 t of sown DM/ ha, and for a $90 \%$ plantain- $10 \%$ white clover mixture it was $2.55 \mathrm{t}$ of total $\mathrm{DM} / \mathrm{ha}$ and $2.64 \mathrm{t}$ of sown $\mathrm{DM} / \mathrm{ha}$. Therefore, these species may have the ability to interact, but if they are not present in large enough proportions in a pasture mixture, the expression of this interaction will generally not be strong enough to detect (Kirwan et al. 2009). These calculations also demonstrate the predictive ability of the modelling approach to evaluate mixtures beyond those included in the experimental design.

So far, the average interspecific interactions across the two sowing methods have been discussed. Only the interaction between ryegrass and white clover depended on sowing method, significantly so in Year 1 (Table 2). The diversity effect of an even ryegrass-white clover mixture with the two species drilled in the same rows in Year 1 was $6.27 \mathrm{t}$ of total DM/ha $(4.36+-7.62 \times 0.5$ $\times 0.5 \times-1)$ and $6.75 \mathrm{t}$ of sown DM/ha $(4.85+-7.60$ $\times 0.5 \times 0.5 \times-1)$. By comparison, the diversity effect of the same mixture with the two species separated in alternate drill rows was $2.46 \mathrm{t}$ of total DM/ha $(4.36+$ $-7.62 \times 0.5 \times 0.5 \times 1)$ and $2.95 \mathrm{t}$ of sown $\mathrm{DM} / \mathrm{ha}(4.85$ $+-7.60 \times 0.5 \times 0.5 \times 1)$. Therefore, separating ryegrass and white clover in alternate drill rows suppressed the interaction effect rather than increasing it. Possible reasons for this difference may have been a lower soil $\mathrm{N}$ status and light interception, which were not quantified in this experiment.

Overall, the results show that the yield of the pasture mixtures depended on the identity effects, interaction effects and relative abundance of the species present. There was evidence of greater identity effects for ryegrass than plantain, but stronger pairwise interactions between plantain and white clover than between ryegrass and white clover (Table 2). This meant that the yields were more or less the same between the ryegrass-white clover and plantain-white clover mixtures (Figure 1). There were no additional yield benefits from increasing the number of sown species from two to three in the sward, and by separation of species in alternate drill rows. These results would be dependent on the $\mathrm{N}$ status of the soil and may be modified under different grazing managements and $\mathrm{N}$ recycling in urine.

\section{ACKNOWLEDGEMENTS}

This work was supported by research funding to $\mathrm{S}$. Anderson, S. Dalgety, C. Hassall and S. Vreugdenhil from the Faculty of Agricultural and Life Sciences, Lincoln University.

\section{REFERENCES}

Andrews, M.; James, E.K.; Sprent, J.I.; Boddey, R.M.; Gross, E.; dos Reis Jr, F.B. 2011. Nitrogen fixation in legumes and actinorhizal plants in natural ecosystems: values obtained using ${ }^{15} \mathrm{~N}$ natural abundance. Plant Ecology \& Diversity 4: 131-140.

Black, A.D.; Anderson, S.; Dalgety, S.K. 2017. Identification of pasture mixtures that maximise dry matter yield. Journal of New Zealand Grasslands 79: 103-110.

Black, A.D.; Laidlaw, A.S.; Moot, D.J.; O'Kiely, P. 2009. Comparative growth and management of white and red clovers. Irish Journal of Agricultural and Food Research 33: 33-50.

Black, A.D.; Murdoch, H.M. 2013. Yield and water use of a ryegrass/white clover sward under different nitrogen and irrigation regimes. Proceedings of the New Zealand Grassland Association 75: 157-164.

Cornell, J.A. 2002. Experiments with mixtures: designs, models, and the analysis of mixture data. $3^{\text {rd }}$ Ed. Wiley, Chichester, England. 305 pp.

Cox, J.E. 1978. Soils and agriculture of part Paparua County, Canterbury, New Zealand. New Zealand Soil Bureau Bulletin No. 34. New Zealand Department of Scientific and Industrial Research, Wellington, New Zealand. 128 pp.

Harris, W.; Thomas, V.J. 1973. Competition among pasture plants III. Effects of frequency and height of cutting on competition between white clover and two ryegrass cultivars. New Zealand Journal of Agricultural Research 16: 49-58.

Hurst, R.G.M.; Black, A.D.; Lucas, R.J.; Moot, D.J. 2000. Sowing strategies for slow-establishing pasture species on a North Otago dairy farm. Proceedings of the New Zealand Grassland Association 62: 129-135.

Kirwan, L.; Connolly, J.; Finn, J.A.; Brophy, C.; Lüscher, A.; Nyfeler, D.; Sebastià, M.-T. 2009. Diversity-interaction modelling: estimating contributions of species identities and interactions to ecosystem function. Ecology 90: 2032-2038.

Stewart, A.; Kerr, G.; Lissaman, W.; Rowarth, J. 2014. Pasture and forage plants for New Zealand, 4th Ed. New Zealand Grassland Association, Dunedin, New Zealand. $139 \mathrm{pp}$. 
